Abstracta Iranica Iranica

Revue bibliographique pour le domaine irano-aryen

Volume 40-41 | 2019

Comptes rendus des publications de 2017-2018

\title{
Götz König. Studien zur Rationalitätsgeschichte im älteren Iran. Ein Beitrag zur Achsenzeitdiskussion
}

\section{Kianoosh Rezania}

\section{OpenEdition}

1 Journals

\section{Édition électronique}

URL : http://journals.openedition.org/abstractairanica/50568

DOI : 10.4000/abstractairanica.50568

ISBN : 1961-960X

ISSN : 1961-960X

Éditeur :

CNRS (UMR 7528 Mondes iraniens et indiens), Éditions de l'IFRI

Référence électronique

Kianoosh Rezania, « Götz König. Studien zur Rationalitätsgeschichte im älteren Iran. Ein Beitrag zur

Achsenzeitdiskussion», Abstracta Iranica [En ligne], Volume 40-41 | 2019, document 7, mis en ligne le 30 décembre 2019, consulté le 24 avril 2021. URL : http://journals.openedition.org/abstractairanica/ 50568 ; DOI : https://doi.org/10.4000/abstractairanica.50568

Ce document a été généré automatiquement le 24 avril 2021

Tous droits réservés 


\title{
Götz König. Studien zur Rationalitätsgeschichte im älteren Iran. Ein Beitrag zur Achsenzeitdiskussion
}

\author{
Kianoosh Rezania
}

\section{RÉFÉRENCE}

Götz König. Studien zur Rationalitätsgeschichte im älteren Iran. Ein Beitrag zur

Achsenzeitdiskussion. Wiesbaden: Harrassowitz, 2018, viii+244 p. (Iranica26)

1 In this refreshing book, Götz König scrutinizes the history of rationality in preAchaemenid and Achaemenid Iran by dealing with the theory of axial age. The book comprises five independent but interrelated texts, the first four presented on different occasions, as workshops and courses.

2 In the first text, the author analyzes the first part of Karl Jaspers' Book Vom Ursprung und Ziel der Geschichte (Munich 1949), one of the most prominent contributions to the axial age theory. Jaspers argues that in different cultural areas like China, India and the Occident (somehow including Iran, Israel and Europe), significant intellectual processes -rationality and ethics substituting myth and ritual - emerged more or less simultaneously, but were independent from each other. They mark significant milestones in the history. Jaspers introduces two axial periods, around 500 B.C. and the modern period, each one presented in one part of his book. Whereas the three mentioned cultural areas were - according to Jaspers - isolated, and a mysterious parallelism constitutes the first axial period, cultural contact forms the basis of the second one. Götz König criticizes Jaspers' construction for ignoring the role of Old Iran (Eastern (Avestan) as well as Western (Old Persian) Iran), especially the Achaemenid empire, in the world history, and points out its role as bridge for contacts between the regions from Greece to India. Accordingly, it was only China whose relations with the other cultural regions in ancient times is not (yet) proven. The author postulates that 
Jaspers' intently left the Achaemenid empire aside to reach the mysterious parallelism in the first axial time in his theory.

The second text addresses the demarcation of Iranian religiosity as reflected in the Gathas from the Indo-Iranian one, represented by the Rgveda. He attempts to reduce the demarcation process to a 'minimal divergence' (minime Abweichung) in the ritual practice, namely the prohibition of Haoma libation to the fire in the Zoroastrian ritual practice; instead, the priest himself drinks the Haoma. According to König, this decoupling of Haoma and the fire not only initiated their independent development but also strengthened the position of the priest and gave him the function of knowledge acquisition instead of fire according to the Indo-Iranian tradition.

4 The chapter III discusses the priests' instruments in the process of knowledge acquisition in the ritual, the instruments of vision (daēnā) in the godly sphere. After a lengthy summary of Alberto Cantera's thesis on the function of daēna an the priests' communication with god, the author elaborates this approach by introducing xratu (the intellectual capacity of humans as well as gods) into the Old Avestan epistemology. He points out that the priest's own xratu is the means for questioning Ahura Mazdā, and daēen can provide questioning precisely through xratu.

The fourth text examines the significance of Darius' I 'law' (dāta) for the axiality of world history. It begins with the investigation of the semantics of aṣa/arta and druj/ drauga in the old and Young Avestan texts as well as in the Old Persian inscriptions. König also points out Darius' I use of dāta, designated as 'my law,' instead of a cosmological-ritual term such as arta. According to the author, the relation between Darius and law was a dialectic one: not only law was Darius' will or wish (kāma) but his wish could be nothing other than what law prescribed. According to Götz König, the change of socio-political reference from the cosmic order to a human law marked a watershed in Iranian and by this in human history. The chapter, finally, investigates the role of xratu in legislation.

6 Against the reader's expectation, the concluding chapter, (re)written for this book, does not attempt to affirm the axiality of the Achaemenid period. The author highlights the characteristics of the Achaemenid period, namely the formation of a world empire consisting of diverse countries with (limited) autonomy and with 'law' (dāta) at its center. Because of its partly synonymous use with (king's) wish (kāma), this law possessed an ambivalent character. However, it established égalité in the whole empire. This even applied to Darius himself as well: he subordinated himself to his law. Götz König underlines that research in the domain of Achaemenid art and Achaemenid inscriptions have shown that the Old Persian inscriptions as well as Achaemenid art proceeded from particular and individual to general. The evidence leads the author to conclude that the Achaemenids reached a perception of mankind as independent of its race, language and religion. This Achaemenid project, however, failed or was obliged to fail. It did not yield the perpetual exercise of rationality and homology among inhabitants of the empire, but a dialectic of homology and tension, as well as rationality and charisma. 


\section{AUTEURS}

\section{KIANOOSH REZANIA}

Ruhr-Universität, Bochum 